\title{
Coastal ice-core record of recent northwest Greenland temperature and sea-ice concentration
}

\author{
Erich C. OSTERBERG, Robert L. HAWLEY, Gifford WONG, Ben KOPEC, David FERRIS, \\ Jennifer HOWLEY
}

Department of Earth Sciences, Dartmouth College, Hanover, NH, USA

Correspondence: Erich C. Osterberg <erich.c.osterberg@dartmouth.edu>

\begin{abstract}
Coastal ice cores provide an opportunity to investigate regional climate and sea-ice variability in the past to complement hemispheric-scale climate reconstructions from ice-sheet-interior ice cores. Here we describe robust proxies of Baffin Bay temperature and sea-ice concentration from the coastal 2Barrel ice core collected in the Thule region of northwest Greenland. Over the 1990-2010 record, 2Barrel annually averaged methanesulfonic acid (MSA) concentrations are significantly correlated with May-June Baffin Bay sea-ice concentrations and summer temperatures. Higher MSA is observed during warmer years with less sea ice, indicative of enhanced primary productivity in Baffin Bay. Similarly, 2Barrel annually averaged deuterium excess (d-excess) values are significantly correlated with annual Baffin Bay sea-ice concentrations and summer and annual temperatures. Warm (cool) years with anomalously low (high) sea-ice concentration are associated with proportionally more (less) low-d-excess Baffin Bay moisture at the ice-core site. Multilinear regression models incorporating 2Barrel MSA, d-excess and snow accumulation account for $38-51 \%$ of the Baffin Bay sea-ice and temperature variance. The annual temperature model is significantly correlated with temperatures throughout most of Greenland and eastern Arctic Canada due to the strong influence of the North Atlantic Oscillation and Atlantic Multidecadal Oscillation.
\end{abstract}

KEYWORDS: climate change, ice and climate, ice core, sea ice

\section{INTRODUCTION}

Arctic sea-ice extent and thickness has declined at an accelerating rate over the past several decades, responding to and amplifying rapid Arctic warming (Hartmann and others, 2013) through ice-albedo feedbacks (Serreze and others, 2007; Perovich and Richter-Menge, 2009; Cavalieri and Parkinson, 2012). Sea-ice loss has strongly modified the climate, ocean circulation, storm tracks and ecology of the Arctic (Dieckmann and Hellmer, 2010), but our understanding of sea-ice extent and variability prior to the 20th century is limited (Perovich and Richter-Menge, 2009; Kinnard and others, 2011; Abram and others, 2013). The Greenland ice sheet (GIS) has likewise responded to rising summertime temperatures with increases in the extent of surface melt (Hall and others, 2013) and increasing rates of mass loss (Alley and others, 2010; Shepherd and others, 2012). In northwest Greenland, mass loss accelerated in 2005 due to higher surface melt and runoff and increasing ice discharge, despite higher annual snowfall rates (Sasgen and others, 2012; Hawley and others, 2014). Given the projections of $5-15 \mathrm{~cm}$ of sea-level rise by 2100 from GIS mass loss alone under SRES (Intergovernmental Panel on Climate Change (IPCC) Special Report on Emissions Scenarios) A1B (Yoshimori and Abe-Ouchi, 2012), it is critical to understand both how the climate around Greenland changed in the past and how the ice sheet responded to those changes, especially during past warm periods like the Medieval Climate Anomaly and earlier Holocene Climatic Optimum (e.g. Vinther and others, 2009).

Ice cores from Greenland provide high-resolution (seasonally to annually resolved) proxy records of past temperature, accumulation and atmospheric circulation. Most Greenland ice cores have been collected from the dry snow zone in the high ( $>2500 \mathrm{~m}$ elevation) inland part of the ice sheet, producing invaluable records of North Atlantic and Northern Hemisphere climate and environmental change spanning the past $\sim 120000$ years (Mayewski and others, 1997; Andersen and others, 2004; Masson-Delmotte and others, 2005). In contrast, coastal ice cores provide the opportunity to develop more regional-scale records of climate conditions along the climatologically sensitive and dynamic ice-sheet margins, as well as robust records of past sea-ice variability due to the proximity and greater influence of neighboring marine areas (Isaksson and others, 2005; Abram and others, 2013; Sinclair and others, 2014).

The ice-sheet margins also preserve valuable landscape records of past ice-sheet extent (Levy and others, 2012) and lake sediment records of past summertime temperature (Axford and others, 2013). Combining these records with a coastal ice core influenced by the same ice-marginal conditions presents the opportunity for multi-proxy reconstructions of past temperature and ice-sheet extent. Temperature and precipitation changes around the Greenland coast show pronounced regional variability and often opposing anomaly patterns due to the strong influence of atmospheric circulation patterns like the North Atlantic Oscillation (NAO), a 'seesaw' of atmospheric mass with centers of action in the Icelandic low and Azores high that is most active in the wintertime (Hurrell, 1995; Hanna and others, 2013). NAO positive conditions are associated with a stronger Icelandic-low-Azores-high pressure gradient, with anomalously strong (weak) southerly flow to the east (west) of Greenland, resulting in warmer and wetter conditions in northeast Greenland and cooler and dryer conditions in northwest Greenland (Hurrell, 1995; Hanna and others, 2013; Mernild and others, 2014). Glacier 


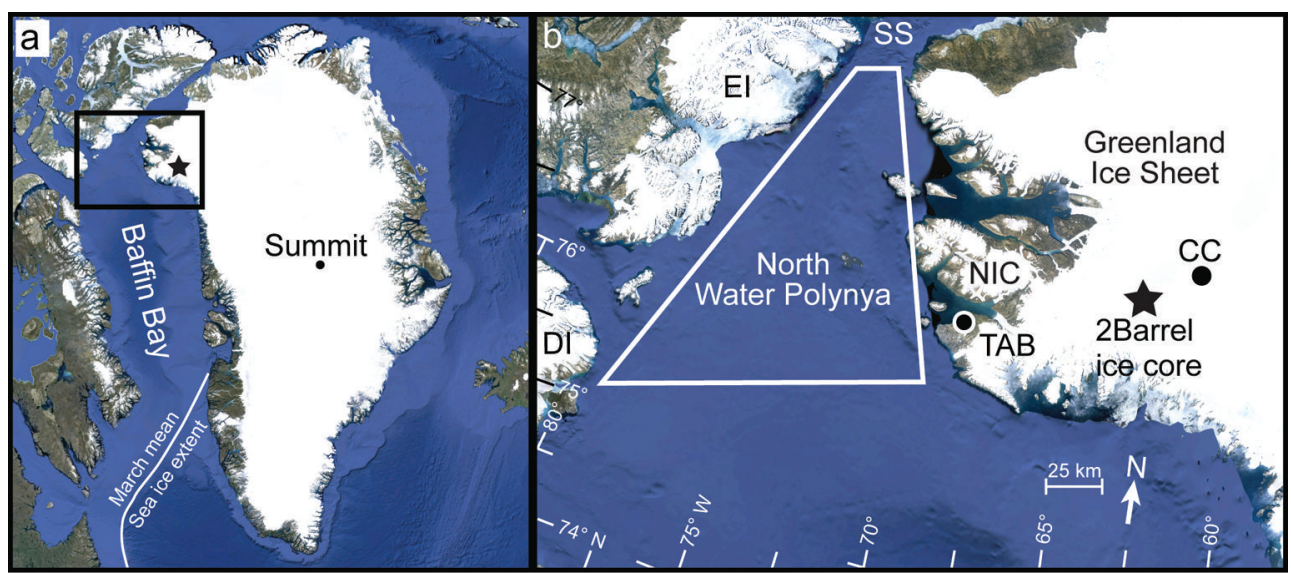

Fig. 1. Maps of Greenland (a) and the northern Baffin Bay region (b), showing locations discussed in the text including the 2Barrel core location (star), 100 km from the Thule coast. TAB: Thule Air Base; CC: Camp Century; NIC: North Ice Cap; NOW: North Water Polynya; SS: Smith Sound; El: Ellesmere Island; DI: Devon Island. Also shown in (a) is the 1979-2012 average March sea-ice boundary (maximum annual extent) (Rayner and others, 2003). Baffin Bay south of Smith Sound is typically sea-ice free during the September minimum extent.

surface mass balance responds to these regional temperature and precipitation anomalies (Sasgen and others, 2012), so it is critical to collect coastal ice cores close to the ice margins of interest.

Here we describe temperature and sea-ice proxy records from the coastal 2Barrel ice core, collected from a site $\sim 100 \mathrm{~km}$ from the northwest Greenland coast (Fig. 1). This is a $21 \mathrm{~m}$ long reconnaissance ice core spanning 19902010 , collected to evaluate the suitability of this site for the recovery of a deeper, Holocene-length ice core. The core site is close enough to the coast to be strongly influenced by regional conditions in northern Baffin Bay (a significant local moisture source), but high enough on the ice sheet that surface melt does not significantly alter the ice chemistry record. We focus here on temperature and sea-ice concentrations because these climate parameters have changed dramatically in northwest Greenland since 1990 and would be valuable proxies in a Holocene-length record. The instrumental record from Thule shows a $1.5^{\circ} \mathrm{C}$ increase in annual temperatures since 1952 , and a faster $3.3^{\circ} \mathrm{C}$ increase since 1991 with a summer and winter warming of $3.4^{\circ} \mathrm{C}$ and $5.4^{\circ} \mathrm{C}$, respectively (Wong and others, 2015). This regional increase in temperature has driven the loss of sea ice in Baffin Bay during all seasons since at least the 1950s, with the largest sea-ice concentration declines in summer $\left(-4.2 \%\right.$ decade $\left.^{-1}\right)$ and fall $\left(-5.2 \%\right.$ decade $\left.^{-1}\right)$ from 1990 to 2012 (Rayner and others, 2003).

The mean annual temperature of the 2 Barrel site is estimated to be $-22.5^{\circ} \mathrm{C}$ based on nearby $10 \mathrm{~m}$ firn temperatures (Benson, 1962; Polashenski and others, 2014) and extrapolation from the $-10.5^{\circ} \mathrm{C}$ mean annual temperature at Thule Air Base (1991-2012) using a $7.5^{\circ} \mathrm{C} \mathrm{km}^{-1}$ lapse rate (Hall and others, 2013). This is also consistent with limited data from the Greenland Climate Network (GC-Net) automatic weather station, GITS, at Camp Century (Fig. 1), located $50 \mathrm{~km}$ to the east at $1869 \mathrm{~m}$ elevation on the ice sheet, which recorded mean annual temperatures of $-23.4^{\circ} \mathrm{C}$ from 2001 to 2002 and $-22.7^{\circ} \mathrm{C}$ from 2006 to 2007 (Steffen and Box, 2001). Hourly temperatures at GITS range from maximums of $+1^{\circ} \mathrm{C}$ in summer to minimums of $-53^{\circ} \mathrm{C}$ in winter (Steffen and Box, 2001). In addition to the significant negative correlation between Thule temperatures and the NAO described above
(NAO+ conditions associated with anomalously cool Thule temperatures), northwest Greenland temperature is also significantly influenced by the Atlantic multi-decadal oscillation (AMO). The AMO is the dominant multi-decadal mode of North Atlantic sea surface temperature variability, hypothesized to result from changes in Atlantic meridional overturning circulation strength (Schlesinger and Ramankutty, 1994). AMO positive conditions are associated with anomalously high summertime temperatures in northwest Greenland and throughout most of the North Atlantic (Hanna and others, 2013).

Annual snow accumulation at 2 Barrel averaged $0.51 \mathrm{~m}$ w.e. (range $0.27-0.89 \mathrm{~m}$ w.e.) from 1990 to 2010 , and the accumulation time series is significantly correlated to the instrumental Thule precipitation record $(r=0.63$, $p<0.01$ ), with both records indicating a precipitation increase since 1990 (Hawley and others, 2014; Wong and others, 2015). Measured daily precipitation at Thule from 1952 to 2012 has a strong summer-fall bias, with $64 \%$ of annual precipitation (rain and snow) falling from June to November (Wong and others, 2015). However, GITS data show a more even distribution of snow accumulation throughout the year, with $36 \%$ accumulating in summer, $31 \%$ in fall and $17 \%$ in each of winter and spring (Steffen and Box, 2001). Our analysis of daily precipitation data indicates that precipitation at Thule and GITS (and therefore 2Barrel) typically falls during times of southerly and southwesterly flow originating over Baffin Bay, accentuated by ice-sheet orographic forcing.

The dynamics of northern Baffin Bay sea ice are influenced by the North Water (NOW) Polynya, a predominantly latent-heat polynya (Melling and others, 2001) bounded by Ellesmere and Devon Islands in the west and the Thule region of Greenland in the east from $75^{\circ} \mathrm{N}$ to $78.5^{\circ} \mathrm{N}$ (Fig. 1b) (Vidussi and others, 2004). Pack ice flows southward through the narrow Nares Strait due to northerly winds and currents, forming an ice bridge in northern Smith Sound that blocks ice from moving into Baffin Bay (Barber and others, 2001). The polynya is $95 \%$ covered by ice in January, but starts to open up in April and reaches its maximum extent in July (Vidussi and others, 2004). The NOW Polynya is the most biologically productive region of the Canadian Arctic (Stirling, 1997), with phytoplankton 
blooms typically peaking in May and June as ice cover retreats (Mei and others, 2003). Phytoplankton and ice algae blooms emit dimethyl sulfide (DMS) to the atmosphere through the degradation of dimethylsulfoniopropionate, which regulates phytoplankton osmotic pressure (Burgermeister and Georgii, 1991). DMS is subsequently oxidized in the atmosphere to methanesulfonic acid (MSA), which is deposited in precipitation on the GIS with a spring-summer maximum reflecting peak marine production during sea-ice break-up (Jaffrezo and others, 1994; Legrand and others, 1997; Sharma and others, 2012). Marine primary production is the sole source of Arctic MSA (Mulvaney and others, 1992), and we use MSA here to develop proxy records for Baffin Bay sea-ice concentration and temperature.

We also focus on the 2Barrel record of deuterium excess (d-excess), defined as the isotopic deviation from the meteoric waterline: $d$-excess $=\delta D-8 \delta^{18} \mathrm{O}$ (Craig, 1961), where $\delta \mathrm{D}$ and $\delta^{18} \mathrm{O}$ are the parts per thousand deviation of deuterium/hydrogen and ${ }^{18} \mathrm{O} /{ }^{16} \mathrm{O}$ atomic ratios, respectively, from those of Standard Mean Ocean Water. Deuterium excess is primarily sensitive to the sea surface temperature and relative humidity of the moisture source. Vapor that evaporates from cold, polar surface waters with high relative humidity is associated with low d-excess, while warmer subtropical moisture sources with low relative humidity are associated with high d-excess vapor (Merlivat and Jouzel, 1979; Petit and others, 1991). Thus, changes in the temperature or relative humidity of the moisture source, or changes in the relative proportion of subtropical and polar moisture sources, will lead to changes in d-excess at an ice-core site through time (Vimeux and others, 1999; Masson-Delmotte and others, 2005). We describe robust relationships between d-excess in the 2 Barrel ice core and Baffin Bay temperature and sea-ice concentrations.

\section{METHODS}

\section{Barrel ice-core collection}

The 2 Barrel ice core $\left(76.935^{\circ} \mathrm{N}, 63.153^{\circ} \mathrm{W}\right)$ was collected from a site $\sim 100 \mathrm{~km}$ inland from the northwest Greenland coast at an elevation of $1685 \mathrm{~m}$ on the ice sheet (Fig. 1). The core was drilled to $21.3 \mathrm{~m}$ depth in July 2011 using a Kovacs Enterprise Mark III $(7.25 \mathrm{~cm}$ diameter $)$ coring system (Hawley and others, 2014). It was shipped frozen to the Dartmouth Ice Core Laboratory, Hanover, NH, where it was processed, logged, and analyzed for glaciochemistry. The top $1 \mathrm{~m}$ of the snowpack was sampled in a snow pit directly above the drilling site at $10 \mathrm{~cm}$ resolution with pre-cleaned low-density polyethylene bottles by researchers wearing non-particulating Tyvek suits and vinyl gloves (cf. Osterberg and others, 2006). The core site is within the percolation zone with summer surface melting, but refrozen melt layers represent $<3 \%$ of the core length.

\section{Glaciochemical analyses and timescale development}

The ice core was sampled for major-ion, trace-element and stable isotope analyses at $4-10 \mathrm{~cm}$ resolution using a continuous ice-core melter system with discrete sampling (Osterberg and others, 2006). A total of 461 samples were analyzed for an average of 20 samples $\mathrm{a}^{-1}$. Based on the results of Koffman and others (2014), ice-core and snow-pit samples for trace-element analyses were acidified with Optima $^{\mathrm{TM}}$ nitric acid to $3 \%$ concentration under a HEPA clean bench, and allowed to react with the acid at room

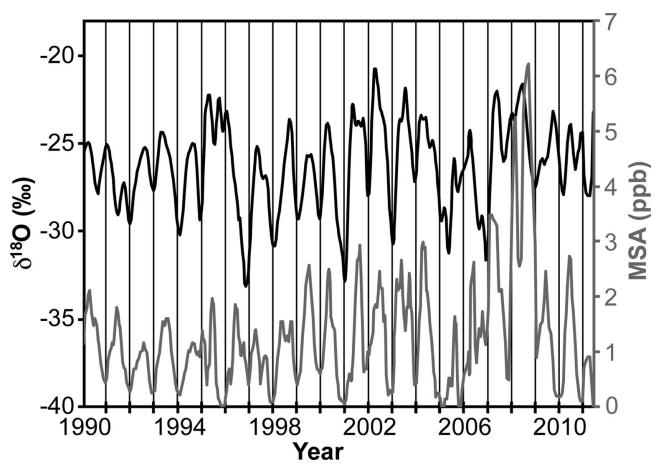

Fig. 2. Stable water isotope $\left(\delta^{18} \mathrm{O}\right.$; black line) ratios and MSA (gray line) concentrations in the 2Barrel ice core, used to develop the annual timescale. Note the consistent summer seasonal peaks in both records, representing summer temperatures $\left(\delta^{18} \mathrm{O}\right)$ and springsummer emissions from phytoplankton in Baffin Bay. Data average 20 samples per year, and are displayed with a five-point smoothing.

temperature for 60 days prior to analyses. We measured stable water isotope ratios ( $\delta \mathrm{D}$ and $\delta^{18} \mathrm{O}$ ), from which we calculate d-excess, using a Picarro L2130-i cavity ringdown analyzer with a typical uncertainty of $\pm 0.6 \%$ for $\delta \mathrm{D}$, $\pm 0.2 \%$ o for $\delta^{18} \mathrm{O}$ and $\pm 0.45 \%$ o for $\mathrm{d}$-excess. Major cation and trace-element sample concentrations $(\mathrm{Na}, \mathrm{Mg}, \mathrm{Ca}, \mathrm{Al}$, $\mathrm{Fe}, \mathrm{S}, \mathrm{K}, \mathrm{Li}, \mathrm{Ti}, \mathrm{Sr}, \mathrm{Cd}, \mathrm{Cs}, \mathrm{Ba}, \mathrm{Pb}, \mathrm{Bi}, \mathrm{U}, \mathrm{As}, \mathrm{V}, \mathrm{Cr}, \mathrm{Mn}, \mathrm{Co}$, $\mathrm{Cu}, \mathrm{Zn}, \mathrm{REEs}$ (rare-earth elements)) were measured by inductively coupled plasma mass spectrometry using a Thermo Element2 at the Climate Change Institute, University of Maine, Orono, USA, as detailed in Osterberg and others (2006). Anion concentrations $\left(\mathrm{SO}_{4}{ }^{2-}, \mathrm{NO}_{3}{ }^{-}, \mathrm{Cl}^{-}\right.$and $\left.\mathrm{MSA}\right)$ were measured using a Dionex ICS 5000 capillary ion chromatography system at Dartmouth with a typical uncertainty of $1.0 \mathrm{ppb}$.

The 2Barrel ice core was annually dated from 1990 to 2010 using robust summertime peaks in MSA, $\delta \mathrm{D}$ and $\delta^{18} \mathrm{O}$ (Fig. 2). The summertime MSA peaks are consistent with its source from marine phytoplankton blooms in Baffin Bay. We estimate a timescale uncertainty of \pm 0.5 years based on repeat independent annual-layer counts. Thus, we do not attempt here to evaluate seasonal ice-core chemistry averages, but rather compare annually averaged ice-core data to seasonal and monthly climate parameters. We annually average the ice-core data based on approximating a 1 January date corresponding with MSA, $\delta \mathrm{D}$ and $\delta{ }^{18} \mathrm{O}$ minima (Fig. 2), so our annual averaging approximates a calendar year (January-December).

\section{Meteorological and climate reanalysis data}

Herein we develop 2Barrel ice-core proxy records for Baffin Bay sea-ice concentrations using sea-ice data from the ERAInterim reanalysis model developed by the European Centre for Medium-Range Weather Forecasts (Dee and others, 2011), averaged over the region $70-78^{\circ} \mathrm{N}, 55-80^{\circ} \mathrm{W}$. We also develop regional temperature proxies from 2 Barrel data using a composite record of temperature for the nearby Thule region developed by Wong and others (2015). This record is based on Danish Meteorological Institute (DMI) stations at Dundas (04200) and Pituffik (04202) (Cappelen, 2013) with missing DMI data replaced with observations from the weather center at Thule Air Base. The resulting daily composite temperature record has no gaps from 1952 to 2012 . 


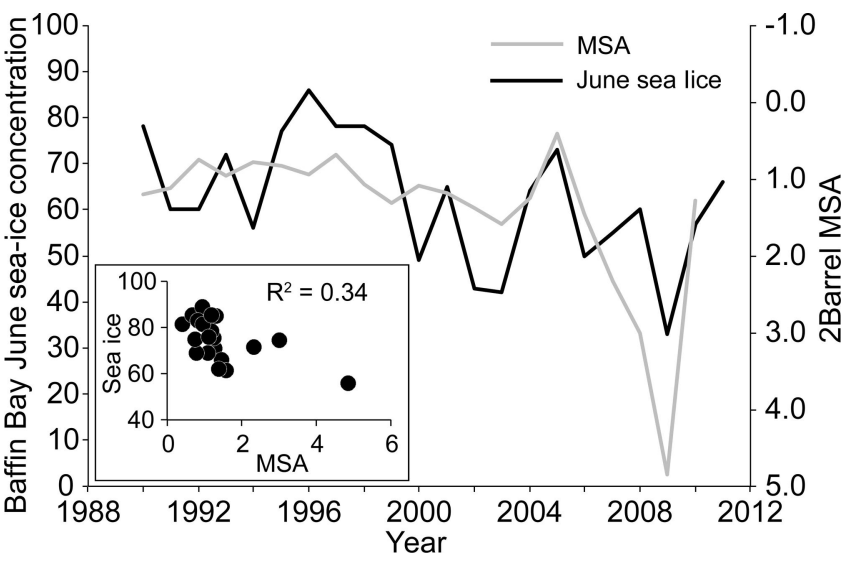

Fig. 3. Annually averaged MSA (gray line) compared to June Baffin Bay sea-ice concentration (black line) from 1990 to 2010. The negative correlation is interpreted to represent increased phytoplankton production and DMS emissions during years with lower Baffin Bay sea-ice concentration.

\section{RESULTS}

\section{Barrel sea-ice proxies}

The 2Barrel ice-core annually averaged MSA concentrations are significantly correlated with Baffin Bay sea-ice concentrations in May $(r=-0.43, p<0.05)$ and June $(r=-0.53$, $p<0.01)$. The negative correlations indicate that years with lower May-June sea-ice concentrations are associated with higher ice-core MSA concentrations. No other month in the sea-ice concentration dataset has a statistically significant correlation with 2Barrel MSA. The strengths of the May and June correlations increase to $-0.46(p<0.05)$ and -0.59 $(p<0.01)$, respectively, if the sea ice is averaged over a smaller region in northern Baffin Bay $\left(72-76^{\circ} \mathrm{N}\right.$; Fig. 3). This

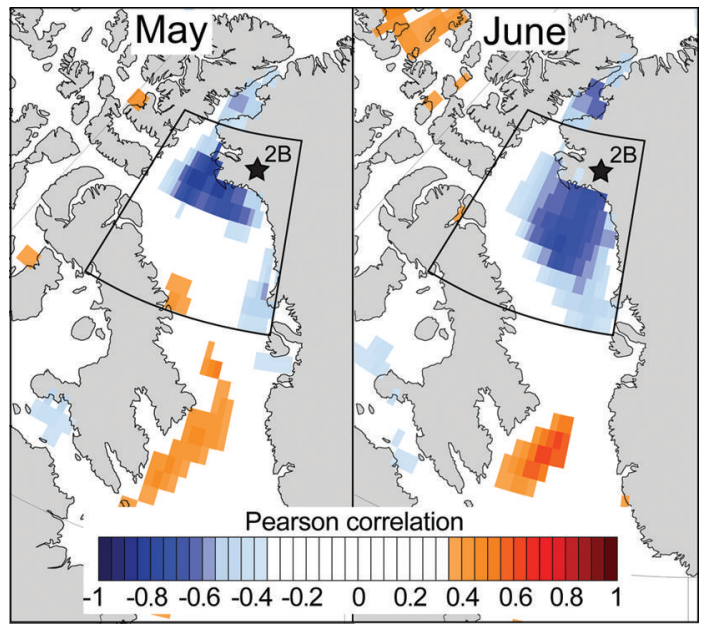

Fig. 4. Spatial correlation map of 2Barrel MSA compared to ERAInterim sea-ice concentration in May (left) and June (right) from 1990 to 2010. The locations of strongest negative correlations in northern Baffin Bay and the North Water Polynya region are indicative of the location of the retreating ice front during these months. An earlier sea-ice retreat is associated with higher MSA concentrations in the 2Barrel ice core, interpreted to result from higher phytoplankton productivity. Only gridcells with significant correlations $(|r|>0.36, p<0.05)$ are shaded. The polygon demarks the region over which Baffin Bay sea-ice extent is averaged for the majority of correlation analyses in the text.

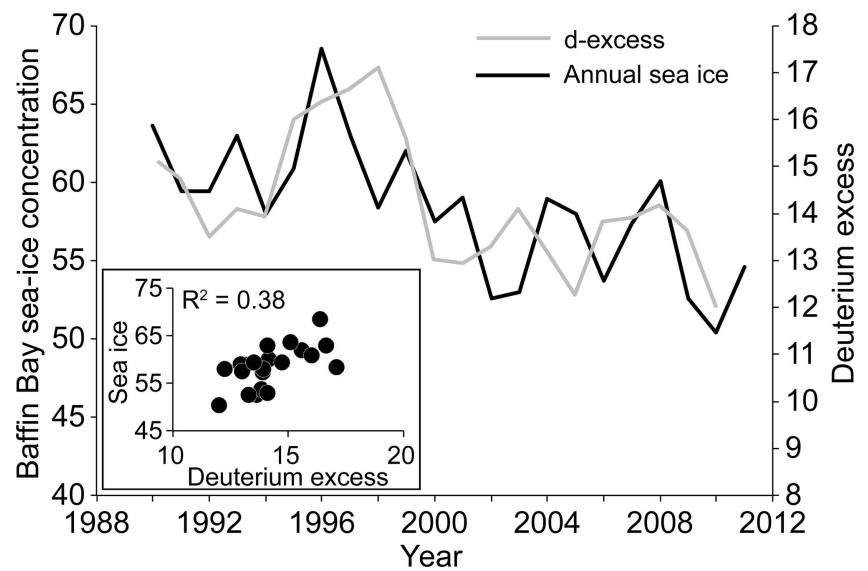

Fig. 5. Annually averaged 2 Barrel d-excess (gray) compared to annually averaged Baffin Bay sea-ice concentration (black) from 1990 to 2010. The positive correlation is interpreted to result from an increased proportion of low d-excess Baffin Bay moisture in years with lower sea-ice concentrations.

is reflected in the spatial correlation plot shown in Figure 4, where the strongest correlations with the 2Barrel MSA record are located along the retreating sea-ice edge of northern Baffin Bay and in the NOW Polynya region.

The 2Barrel d-excess record is strongly correlated $(r=0.62, p<0.005)$ with the annually averaged (JanuaryDecember) Baffin Bay sea-ice concentration. Figure 5 displays the strong positive relationship between the two time series from 1990 to 2010, with the trend of declining Baffin Bay sea-ice concentration associated with progressively lower d-excess values. Figure 6 shows the spatial pattern of the d-excess-sea-ice correlation, with statistically significant positive correlations across the northern half of Baffin Bay. On a monthly basis, 2Barrel d-excess is most strongly correlated with June $(r=0.61, p<0.005)$, October $(r=0.56$, $p<0.01)$ and November $(r=0.55, p<0.01)$ sea-ice concentrations. In general, the larger the decline in sea-ice concentration over the 1990-2010 period, the stronger the

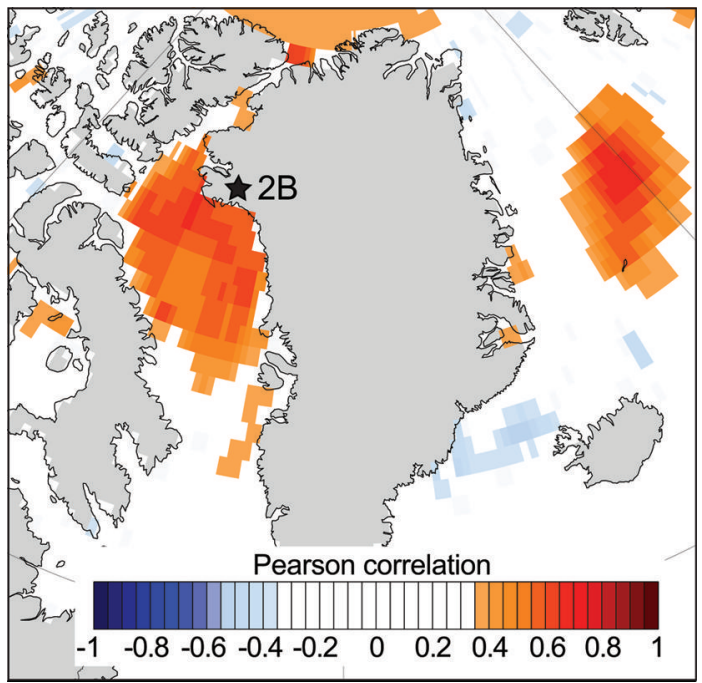

Fig. 6. Spatial correlation map of 2 Barrel d-excess compared to ERA-Interim sea-ice concentration from 1990 to 2010. Sea-ice concentration in each gridcell is correlated against the 2Barrel $\mathrm{d}$-excess record, and the resulting correlation coefficient is shown in color if it is statistically significant $(|r|>0.36, p<0.05)$. 
Table 1. Pearson correlation between monthly Baffin Bay sea-ice concentration and 2Barrel annual average d-excess, and monthly Baffin Bay sea-ice concentration mean, trend and variance from 1990 to 2010 . Months with the strongest correlations are associated with the largest trends and variance

\begin{tabular}{lcccc}
\hline Month & Correl. & Mean SI conc. & $\begin{array}{c}\text { 1990-2010 } \\
\text { SI trend }\end{array}$ & $\begin{array}{c}\text { Year-to-year } \\
\text { variance }\end{array}$ \\
& & & \% decade & \\
& & & & \\
\hline Jan & 0.33 & 92.8 & -5.5 & 23.9 \\
Feb & 0.55 & 95.7 & -3.8 & 11.0 \\
Mar & 0.41 & 96.3 & -2.7 & 7.7 \\
Apr & 0.33 & 94.1 & -1.9 & 6.8 \\
May & 0.48 & 83.9 & -4.0 & 25.8 \\
Jun & 0.61 & 58.9 & -8.0 & 99.7 \\
Jul & 0.25 & 20.8 & -3.6 & 61.8 \\
Aug & 0.08 & 5.9 & -0.3 & 28.5 \\
Sep & 0.01 & 7.0 & 0.9 & 12.3 \\
Oct & 0.56 & 18.7 & -4.1 & 78.9 \\
Nov & 0.55 & 62.9 & -9.4 & 136.7 \\
Dec & 0.40 & 84.5 & -6.3 & 40.9 \\
Annual & $\mathbf{0 . 6 2}$ & $\mathbf{5 8 . 4}$ & $\mathbf{- 0 . 2}$ & $\mathbf{1 8 . 8}$ \\
& & & & \\
\hline
\end{tabular}

correlation with 2Barrel d-excess (Table 1). June and November are associated with the fastest Baffin Bay seaice retreat rates over the 1990-2010 interval, with rates of $-8.0 \%$ decade $^{-1}$ and $-9.4 \%$ decade $^{-1}$, respectively. October sea-ice concentration has declined $4.1 \%$ decade $^{-1}$ over Baffin Bay, but has a faster decline of $8.7 \%$ decade $^{-1}$ in northern Baffin Bay $\left(75-78^{\circ} \mathrm{N}\right)$ closer to Thule. Conversely, August and September sea-ice variability has low $(r=0.01-$ 0.08 ) and insignificant correlations with d-excess because most of Baffin Bay is consistently ice-free during these months (average concentrations of $5.9-7 \%$ ).

June and November also show the largest year-to-year variance in sea-ice concentrations (Table 1), indicating that these months are the most sensitive to external forces like temperature and storms that can significantly influence seaice coverage. This would be expected given that June and November are the months during which sea ice most rapidly melts and expands, on average, during the annual sea-ice cycle in Baffin Bay. Consequently, the sea-ice concentrations in June and November closely track annual sea-ice concentrations, with each representing $76 \%$ of the annual sea-ice variance.

Combining the 2Barrel MSA and d-excess annually averaged data produces a multilinear regression model of spring-summer (May-July (MJJ)) Baffin Bay sea-ice concentration that explains $51 \%$ of the sea-ice variance $\left(\mathrm{SI}_{\mathrm{MJJ}}=\right.$ $-4.42 \times d$-excess $-2.79 \times \mathrm{MSA}+22.4 ; \quad r=0.72, \quad p<0.001)$. Thus, a Holocene-length record from the 2 Barrel site would provide valuable information about past summer (51\% variance) and annually averaged (38\% variance) sea-ice variability in Baffin Bay.

\section{Barrel temperature proxies}

Stable isotope ratios $\left(\delta^{18} \mathrm{O}\right.$ and $\left.\delta \mathrm{D}\right)$ have traditionally been used as temperature proxies in ice cores, but 2 Barrel annually averaged $\delta^{18} \mathrm{O}$ is only weakly correlated with summer (June-August (JJA); $r=0.33, p<0.1$ ) and fall (September-November (SON); $r=0.31, p<0.1)$ temperatures at Thule. However, we find significant 2 Barrel temperature proxies through the strong relationship between temperature

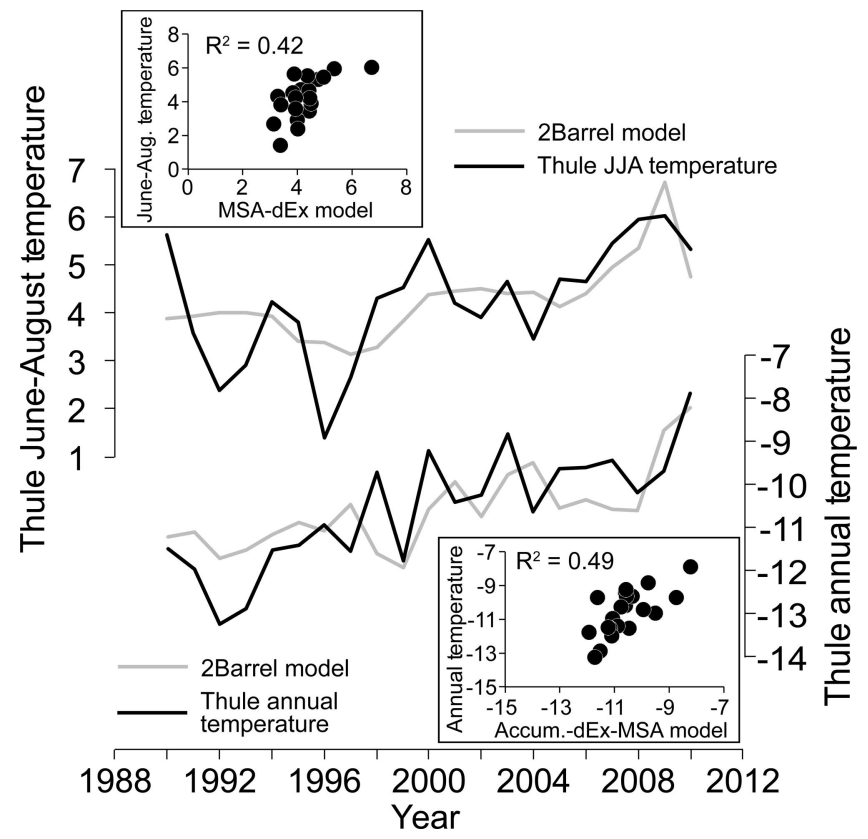

Fig. 7. Summer (top) and annual (bottom) Thule temperatures (black) compared to 2Barrel regression models (gray) using MSA and d-excess (summer), and MSA, d-excess and accumulation (annual).

and sea-ice extent in the instrumental period. Baffin Bay seaice concentrations are significantly correlated $(p<0.01)$ with Thule temperatures from 1979 to 2012 in the winter $(r=$ $-0.67)$, spring $(r=-0.51)$, summer $(r=-0.59)$, fall $(r=-0.80)$ and annually $(r=-0.64)$. It therefore follows that 2 Barrel annually averaged MSA $(r=0.57, p<0.005)$ and d-excess $(r=-0.38, p<0.05)$ are likewise significantly correlated with Thule summer temperatures from 1990 to 2010. Higher summertime temperatures are associated with less summer sea ice, higher MSA from marine phytoplankton, and lower d-excess. A multilinear regression model incorporating the 2Barrel MSA and d-excess record explains $42 \%$ of the Thule summertime temperature variance $\left(T_{\mathrm{JJA}}=-0.26 \times \mathrm{d}\right.$-excess + $0.67 \times \mathrm{MSA}+7.1 ; r=0.65, p<0.01)$. The 2 Barrel summer temperature model is significantly correlated with summer temperatures in northern Baffin Bay and adjacent northwest Greenland and eastern Baffin Island coastlines.

Wong and others (2015) show that the 2Barrel snow accumulation record is significantly correlated with the Thule annual precipitation record from 1990 to 2010. 2Barrel accumulation is also significantly correlated with spring (MAM; $r=0.49, p<0.05$ ), autumn (SON; $r=0.45$, $p<0.05$ ), winter (DJF; $r=0.46, p<0.05)$ and annual Thule temperatures $(r=0.39, p<0.05)$. Thus, by combining the MSA, d-excess and annual 2 Barrel snow accumulation in a mulitilinear regression model, we develop a robust proxy for annual Thule temperature $\left(T_{\text {ann }}\right)$ that explains $49 \%$ of the instrumental Thule temperature variance $\left(T_{\text {ann }}=-0.22 \times\right.$ $\mathrm{d}$-excess + 0.74 $\times \mathrm{MSA}+5.17 \times$ Accum - 11.1; $r=0.70$, $p<0.01$; Fig. 7). This annual temperature regression model is strongly correlated $(r>0.7, p<0.01)$ with ERA-Interim annual surface temperatures throughout most of Greenland, Baffin Bay and eastern Arctic Canada (Fig. 8). Note, however, that temperatures on the northeast coast of Greenland and into the Greenland Sea are weakly or not significantly correlated, which is consistent with temperature patterns associated with both the NAO and AMO. 


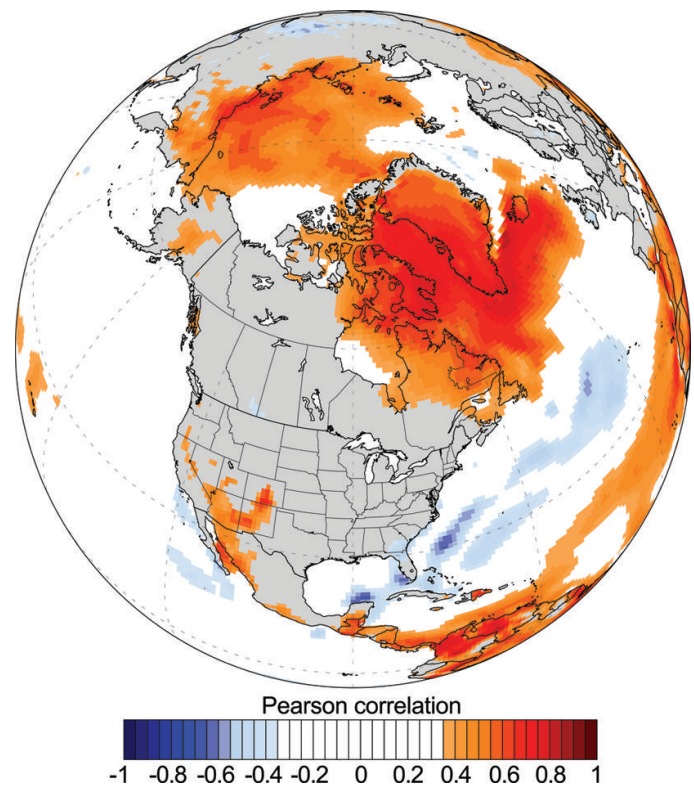

Fig. 8. Spatial correlation map of the 2Barrel MSA-d-excessaccumulation regression model of annual Thule temperature compared to ERA-Interim annual temperatures. The large area of significant correlation from the eastern Canadian Arctic to East Greenland is indicative of the combined importance of the NAO and $\mathrm{AMO}$ for temperature in these areas. Only gridcells with significant correlations $(|r|>0.36, p<0.05)$ are shaded.

\section{DISCUSSION}

\section{MSA-climate relationships}

We find statistically significant negative correlations between May-June sea-ice concentrations and 2Barrel MSA, and suggest that larger open-water areas and a longer ice-free season (associated with lower sea-ice concentration) lead to enhanced phytoplankton production and higher DMS emissions in northern Baffin Bay and the NOW Polynya. Sharma and others (2012) similarly found rising MSA concentrations at Arctic aerosol-monitoring stations (Alert; Barrow; Ny-Ålesund) over the past two decades, attributed to declining sea-ice concentrations. In particular, satellite studies show that the strongest blooms occur along the retreating sea-ice edge (Perrette and others, 2011), consistent with the locations of our May-June MSA-sea-ice correlations (Fig. 6). We hypothesize that the MSAtemperature relationship is similarly mediated by sea-ice concentration, rather than a direct mechanism by which temperature affects productivity or DMS oxidation.

Although MSA has been used extensively as a sea-ice proxy in ice cores from Antarctica, comparatively few records exist for the Arctic (Abram and others, 2013). In records from both the Arctic and Antarctic, the sign of the MSA-sea-ice relationship (positive or negative) varies from site to site and sometimes through time (Abram and others (2013) provide a comprehensive review). Similar to the 2Barrel record, the MSA record from Penny Ice Cap, Baffin Island, in southern Baffin Bay is negatively correlated with Baffin Bay sea-ice extent from 1870 to 1991 (Fisher and others, 1998; Kinnard and others, 2011). Negative MSAsea-ice relationships are also documented in near-coastal ice cores collected from the Ross Sea (Rhodes and others, 2009, 2012; Sinclair and others, 2014) and Amundsen Sea (Criscitiello and others, 2013) sectors of Antarctica, and at some inland Antarctic locations (Sneed and others, 2011).
These studies all propose a similar dependence of ice-core MSA on the extent and duration of open water and its positive influence on primary production. Interestingly, the Lomonosovfonna (Svalbard) ice-core MSA record also shows a negative MSA-sea-ice correlation from 1920 to 1997, but the correlation is positive prior to 1920 (Isaksson and others, 2005). The authors attribute the higher MSA before 1920, when sea ice was more extensive (Little Ice Age), to higher productivity from increased vertical stability of Barents Sea surface water (Isaksson and others, 2005).

Elsewhere, however, the sea-ice-MSA correlation is consistently positive; higher MSA ice-core concentrations are associated with increases in sea-ice extent. For example, ice-core records from the Greenland interior at Summit (Legrand, 1997), NorthGRIP (Andersen and others, 2004; Kinnard and others, 2011), and at 20D in south-central Greenland (Whung and others, 1994) all show a significant declining MSA trend through the 20th century and a positive correlation with sea-ice extent. In Antarctica, ice cores from Law Done (Curran and others, 2003), South Pole (Meyerson and others, 2002; Sneed and others, 2011) and the Ross Sea region (Welch and others, 1993) also show consistent positive MSA-sea-ice correlations. Curran and others (2003) interpreted the Law Dome record as responding to the size of the seasonal sea-ice zone; a larger winter sea-ice extent is associated with a larger region of sea-ice break-up in the spring-summer. This is consistent with the observations of large blooms along retreating sea-ice edges (Perrette and others, 2011), in that more expansive winter sea ice creates a larger area and duration of retreating sea-ice edges during the subsequent summer (Curran and others, 2003; Abram and others, 2013).

The records noted above highlight the critical importance of understanding the regional climate and sea-ice dynamics that influence an ice-core site in order to correctly interpret an MSA proxy record. Ice cores from high on the ice sheet receive their moisture from further afield than lowerelevation coastal sites. Interior cores may integrate air masses from a larger region that varies in size and location through time, with changes in atmospheric circulation, complicating interpretations (Mayewski and others, 1997; Vimeux and others, 1999; Masson-Delmotte and others, 2005). Baffin Bay is restricted in size and experiences neartotal ice cover in the winter even under today's relatively warm climate. Thus, warmer and colder periods during the Holocene will influence the time-integrated area of ice-free water in the spring-fall, but will not significantly change the overall area of Baffin Bay experiencing seasonal sea-ice cover and spring break-up that could lead to positive MSAsea-ice relationships. We therefore hypothesize that the 2Barrel site is well positioned to maintain a negative MSAsea-ice relationship back through the Holocene, providing a valuable proxy for Baffin Bay sea-ice concentration. This hypothesis is supported by the consistent negative MSA-seaice relationship observed in the Penny Ice Cap core during the large temperature and sea-ice changes over the past 120 years (Fisher and others, 1998; Kinnard and others, 2011). However, the brevity of the 2 Barrel record precludes our ability to directly assess the stationarity of the MSA-sea-ice relationship through time, so non-stationarity must be considered if a longer record is recovered from this site.

Many ice cores also show a significant positive or negative relationship between sea-ice and sea-salt sodium or chloride concentrations (Grumet and others, 2001; Rankin and others, 
2002; Wolff and others, 2003; Kinnard and others, 2006; Sneed and others, 2011; Criscitiello and others, 2013; Sinclair and others, 2014). We note that the 2Barrel sea-salt sodium and chloride records have weak positive correlations with sea-ice concentrations from August through October $(r<0.35, p<0.1)$. The positive correlation and fall bias suggest that larger fall sea-ice extents lead to enhanced frost flower formation on new frazil ice (Rankin and others, 2002), and consequently more sea salt advected to the 2 Barrel site. High-salinity snow blowing from the sea-ice surface has also been implicated as a significant source of polar sea-salt aerosol (Yang and others, 2008; Levine and others, 2014), which would likewise create a positive correlation between 2Barrel sea-salt and sea-ice concentration. The bursting of white cap bubbles on the open ocean, in proportion to average wind speeds, has also been interpreted as a key seasalt source at other ice-core sites (Fischer and others, 2007; Osterberg and others, 2014), but would likely result in a negative correlation with sea-ice concentration. It is likely that all these sources contribute in some proportion to 2Barrel sea-salt flux, and consequently sea salt is not as sensitive a sea-ice proxy as MSA or d-excess at the 2 Barrel site.

\section{Deuterium-excess-climate relationships}

We hypothesize that the positive correlation between Baffin Bay sea-ice concentration and 2Barrel d-excess results from changes in the relative balance of polar versus subtropical moisture sources influencing 2Barrel on a year-by-year basis. In years with a lower (higher) Baffin Bay sea-ice concentration, proportionally more (less) of the moisture reaching 2Barrel is low d-excess vapor sourced from ice-free regions of Baffin Bay. B.G. Kopec and others (unpublished information) find the same relationship between d-excess and Baffin Bay sea-ice extent in precipitation samples collected monthly at Alert, Eureka and Cambridge Bay, Canada, from 1990 to 2012. Using d-excess, they suggest that the proportion of Arctic moisture at these sites increases $13.9 \pm 3.9 \%$ per $10^{5} \mathrm{~km}^{2}$ of Baffin Bay sea-ice loss (B.G. Kopec and others, unpublished information).

In contrast, Sinclair and others (2014) find a negative correlation between sea-ice area and d-excess in the coastal Whitehall Glacier ice core collected in the Ross Sea region of Antarctica. However, this is because higher sea-ice extent is related to stronger southerly winds advecting ice northwards into the Ross Sea. These southerly winds concurrently increase the size of the Ross Sea Polynya, thereby increasing the proportion of low d-excess moisture reaching the nearby Whitehall Glacier ice-core site. Thus, the relationship between d-excess, local moisture proportion and polynya size is the same at 2 Barrel and Whitehall Glacier. The contrasting correlations relate, instead, to the opposing relationships between polynya size and regional sea-ice extent, which is a positive relationship in the Ross Sea and a negative relationship in Baffin Bay.

Our hypothesis is that the significant negative correlation between 2Barrel d-excess and regional air temperature is due to the strong influence of temperature on sea-ice concentration, and the sea-ice-d-excess relationship described above. Ice-core d-excess records have often been interpreted as representing changing sea surface temperatures (SST) at the moisture source region (Vimeux and others, 1999; Masson-Delmotte and others, 2005), but an increase in Baffin Bay SST would lead to an increase in d-excess, contrary to the observed relationship. It is further possible that temperature-dependent post-depositional processes at the 2Barrel ice-core site significantly influence the d-excess of the snowpack (Johnson and others, 2000), but our current hypothesis is that any such effect is minor compared to the sea-ice influence.

We also evaluated a potential temperature-d-excess relationship via the NAO, which has a strong negative relationship with northern Baffin Bay temperature as recorded at Thule (annual NAO- $T_{\text {Thule }} r=-0.42$ from 1952 to 2012, $p<0.001$; winter NAO- $T_{\text {Thule }} r=-0.54, p<0.001$ ), and a consequential positive relationship with Baffin Bay sea-ice concentration $\left(\mathrm{SIC}_{\mathrm{BB}}\right.$; annual NAO-SIC $\mathrm{BB} r=0.34$, $p<0.05$ from 1979 to 2012; winter NAO-SIC $\mathrm{BB}_{\mathrm{BB}} r=0.48$, $p<0.005)$. B.G. Kopec and others (unpublished information) find a negative relationship between Canadian Arctic precipitation d-excess and the NAO due to the NAO's strong influence on meridional transport. A positive NAO state is associated with stronger northerly winds in Baffin Bay and eastern Arctic Canada, increasing the proportion of low-dexcess Arctic Ocean moisture to their precipitation sites (B.G. Kopec and others, unpublished information). However, we do not find a statistically significant relationship between 2Barrel d-excess and the NAO from 1990 to 2011. We hypothesize that this is because an increase in low-dexcess Arctic Ocean moisture advection to 2Barrel during NAO positive conditions (due to stronger northerly winds) is offset by a decrease in the advection of low-d-excess Baffin Bay moisture due to enhanced sea-ice concentration.

\section{Influence of the NAO and AMO on Thule temperature}

Although we argue that the 2Barrel ice core is sensitive to local-regional conditions in Baffin Bay, temperatures in this region are sensitive to the state of the $\mathrm{NAO}$ and $\mathrm{AMO}$, so the 2Barrel temperature proxy record is indicative of these important modes of North Atlantic ocean-atmosphere variability. This is reflected in the large region of strong correlation between ERA-Interim annual temperatures and the 2Barrel MSA-d-excess-accumulation regression model for Thule annual temperature (Fig. 8). Correlations between Thule temperature and the NAO and AMO show distinct seasonal biases. The annual NAO-Thule-temperature correlation is $r=-0.46(p<0.001)$ from 1952 to 2012, with the strongest correlations in autumn $(r=-0.62, p<0.001)$ and winter $(r=-0.54, p<0.001)$. The annual AMO-Thuletemperature correlation is $r=0.51(p<0.001)$ from 1952 to 2012 , with the strongest correlation in summer $(r=0.58$, $p<0.001)$. Thus, enhanced wintertime southerly flow in Baffin Bay associated with NAO negative conditions (weakened Icelandic low) increases Thule wintertime temperatures, as do higher summertime SSTs in the North Atlantic. A regression model based on annually averaged $\mathrm{NAO}$ and $\mathrm{AMO}$ indices explains $33 \%$ of the annual Thule temperature variance $(r=0.57, p<0.001$; Fig. 9). Interestingly, the residual signal rises consistently from 1952 to 2012 at a rate of $0.24^{\circ} \mathrm{C}$ decade ${ }^{-1}$. We hypothesize that this residual represents the influence of anthropogenic greenhouse gases superimposed on the annual-decadal temperature variability related to the NAO and AMO.

\section{CONCLUSIONS}

The MSA and d-excess records from the coastal 2Barrel ice core have statistically significant correlations with spring- 


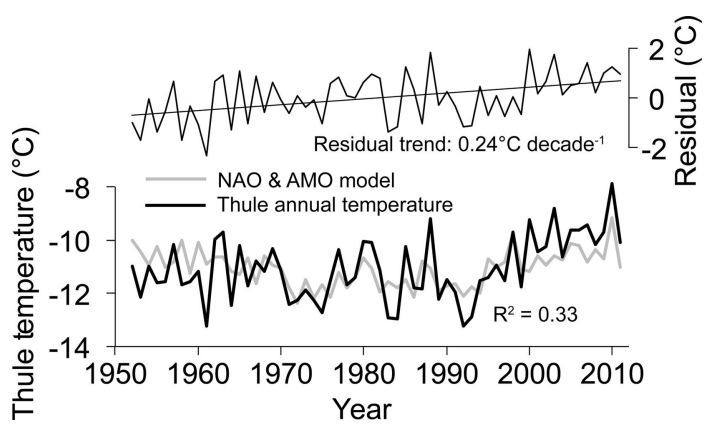

Fig. 9. Thule annually averaged temperature compared to a regression model using annually averaged $\mathrm{AMO}$ and NAO index values, showing that a third of the temperature variance can be ascribed to these modes of ocean-atmospheric circulation. The residual trend rising at $0.24^{\circ} \mathrm{C}$ decade $^{-1}$ is interpreted to represent the influence of anthropogenic greenhouse gases.

summer (May-July) and annual (January-December) sea-ice concentrations in Baffin Bay, and summer (June-August) and annual (January-December) temperatures in Baffin Bay and surrounding areas. We interpret high 2Barrel MSA during low sea-ice years (negative relationship) as evidence for enhanced primary production in Baffin Bay, consistent with negative MSA-sea-ice relationships at coastal Arctic aerosol stations (Sharma and others, 2012) and with the Penny ice core MSA-sea-ice relationship (Fisher and others, 1998; Kinnard and others, 2011). We hypothesize that the 2Barrel site is particularly sensitive to changes in the length of springsummer ice-free conditions because it receives a significant portion of its moisture from a local region (Baffin Bay) that has consistent winter sea-ice cover. This is in contrast to central Greenland ice-core sites and many sites in Antarctica, where the moisture sources impacting the sites are characterized by significant changes in winter sea-ice extent, which can lead to a positive MSA-sea-ice relationship (Curran and others, 2003; Abram and others, 2013).

The strong, positive 2 Barrel d-excess-sea-ice relationships described here provide further support that the core is sensitive to sea-ice conditions in Baffin Bay. Years with lower (higher) Baffin Bay sea-ice concentrations are associated with more (less) low-d-excess Baffin Bay moisture at the ice-core site, consistent with recent studies of Arctic precipitation dexcess (B.G. Kopec and others, unpublished information). Such a sea-ice-d-excess relationship has only been previously documented once from a coastal Antarctic ice-core site in the Ross Sea region (Sinclair and others, 2014).

Due to the strong relationship between temperature and sea-ice concentration in Baffin Bay, the 2Barrel MSA and dexcess time series are significantly correlated with summer and annual Thule temperatures. The multilinear regression models become more robust when the 2Barrel snow accumulation record is also incorporated. Temperatures in northern Baffin Bay are significantly correlated with the $\mathrm{NAO}$ and $\mathrm{AMO}$, particularly during the fall-winter and summer, respectively (Hanna and others, 2013). Thus, although recording local climate conditions in Baffin Bay, the 2Barrel ice core is sensitive to these larger-scale modes of atmospheric and oceanic circulation variability.

Our results indicate that a deeper, Holocene-length record from the 2 Barrel site would be a valuable complement to deep ice-core sites in central, interior Greenland, providing a focused view of Holocene temperature and sea-ice conditions in Baffin Bay. Such a record would be particularly valuable in combination with temperature records from lake cores and landscape records of northwest Greenland ice-margin advance and retreat, using the earlyHolocene climatic optimum as an analog for understanding the sensitivity of the northwest Greenland ice sheet and Baffin Bay sea ice to warmer conditions.

\section{ACKNOWLEDGEMENTS}

The US National Science Foundation Arctic Natural Sciences Program supported this research through grants ARC-0909265 to Hawley and ARC-1107411 to Osterberg. Eric Lutz, Ashley Corbett and Alexandra Giese assisted in collecting the 2Barrel ice core, and Sarah Caughey assisted in assembling the Thule weather station data. We thank CH2M HILL Polar Services, and particularly Kim Derry, Kyli Cosper and Joe Hurley, for assistance with field logistics. We also gratefully acknowledge Sean Birkel and his climate reanalyzer tool (www.cci-reanalyzer.org) for facilitating the production of many of the graphics herein.

\section{REFERENCES}

Abram NJ, Wolff EW and Curran MAJ (2013) A review of sea ice proxy information from polar ice cores. Quat. Sci. Rev., 79, 168-183 (doi: 10.1016/j.quascirev.2013.01.011)

Alley RB and 13 others (2010) History of the Greenland Ice Sheet: paleoclimatic insights. Quat. Sci. Rev., 29(15-16), 1728-1756 (doi: 10.1016/j.quascirev.2010.02.007)

Andersen KK and 49 others (2004) High-resolution record of Northern Hemisphere climate extending into the last interglacial period. Nature, 431(7005), 147-151 (doi: 10.1038/nature02805)

Axford Y, Losee S, Briner JP, Francis DR, Langdon PG and Walker IR (2013) Holocene temperature history at the western Greenland Ice Sheet margin reconstructed from lake sediments. Quat. Sci. Rev., 59, 87-100 (doi: 10.1016/jquascirev.2012.10.024)

Barber DG, Hanesiak JM, Chan W and Piwowar J (2001) Sea-ice and meteorological conditions in northern Baffin Bay and the North Water Polynya between 1979 and 1996. Atmos.-Ocean, 39(3), 343-359 (doi: 10.1080/07055900.2001.9649685)

Benson CS (1962) Stratigraphic studies in the snow and firn of the Greenland ice sheet. SIPRE Res. Rep. 70

Burgermeister S and Georgii HW (1991) Distribution of methanefulfonate, nss sulfate and dimethylsulfide over the Atlantic and the North Sea. Atmos. Environ. A, 25(3-4), 587-595 (doi: 10.1016/0960-1686(91)90056-d)

Cappelen J (2013) Weather and climate data from Greenland 19582012: observation data with description. DMI Tech. Rep. 13-11

Cavalieri DJ and Parkinson CL (2012) Arctic sea ice variability and trends, 1979-2010. Cryosphere, 6(4), 881-889 (doi: 10.5194/tc6-881-2012)

Craig H (1961) Standard for reporting concentrations of deuterium and oxygen-18 in natural waters. Science, 133(346), 1833 (doi: 10.1126/science.133.3467.1833)

Criscitiello AS and 7 others (2013) Ice sheet record of recent sea-ice behavior and polynya variability in the Amundsen Sea, West Antarctica. J. Geophys. Res., 118(1), 118-130 (doi: 10.1029/ 2012jc008077)

Curran MAJ, Van Ommen TD, Morgan VI, Phillips KL and Palmer AS (2003) Ice core evidence for Antarctic sea ice decline since the 1950s. Science, 302(5648), 1203-1206 (doi: 10.1126/ science.1087888)

Dee D and 10 others (2011) The ERA-Interim reanalysis: configuration and performance of the data assimilation system. Q. J.R. Meteorol. Soc., 137(656), 553-597 (doi: 10.1002/qj.828)

Dieckmann GS and Hellmer HH (2010) The importance of sea ice: an overview, 2nd edn. Wiley-Blackwell, Oxford 
Fischer H, Siggaard-Andersen M-L, Ruth U, Röthlisberger R and Wolff E (2007) Glacial/interglacial changes in mineral dust and sea-salt records in polar ice cores: sources, transport, and deposition. Rev. Geophys., 45(1) (doi: 10.1029/2005rg000192)

Fisher DA and 12 others (1998) Penny ice cap cores, Baffin Island, Canada, and the Wisconsinan Foxe Dome connection: two states of Hudson Bay ice cover. Science, 279(5351), 692-695 (doi: 10.1126/science.279.5351.692)

Grumet NS and 7 others (2001) Variability of sea-ice extent in Baffin Bay over the last millennium. Climate Change, 49(1-2), 129-145 (doi: 10.1023/a:1010794528219)

Hall DK, Comiso JC, DiGirolamo NE, Shuman CA, Box JE and Koenig LS (2013) Variability in the surface temperature and melt extent of the Greenland ice sheet from MODIS. Geophys. Res. Lett., 40(10), 2114-2120 (doi: 10.1002/grl.50240)

Hanna E and 6 others (2013) The influence of North Atlantic atmospheric and oceanic forcing effects on 1900-2010 Greenland summer climate and ice melt/runoff. Int. J. Climate, 33(4), 862-880 (doi: 10.1002/joc.3475)

Hartmann DL and 13 others (2013) Observations: atmosphere and surface. In Stocker TF and 9 others eds Climate change 2013: the physical science basis. Contribution of Working Group I to the Assessment Report of the Intergovernmental Panel on Climate Change. Cambridge University Press, Cambridge and New York

Hawley RL and 6 others (2014) Recent accumulation variability in northwest Greenland from ground-penetrating radar and shallow cores along the Greenland Inland Traverse. J. Glaciol., 60(220), 375-382 (doi: 10.3189/2014JoG13J141)

Hurrell JW (1995) Decadal trends in the North-Atlantic Oscillation: regional temperatures and precipitation. Science, 269(5224), 676-679 (doi: 10.1126/science.269.5224.676)

Isaksson E, Kekonen T, Moore J and Mulvaney R (2005) The methanesulfonic acid (MSA) record in a Svalbard ice core. Ann. Glaciol., 42, 345-351 (doi: 10.3189/172756405781812637)

Jaffrezo JL, Davidson Cl, Legrand M and Dibb JE (1994) Sulfate and MSA in the air and snow on the Greenland Ice Sheet. J. Geophys. Res., 99(D1), 1241-1253 (doi: 10.1029/ 93jd02913)

Johnson SJ, Clausen H, Cuffey KM, Hoffman G, Schwander J and Creyts TT (2000) Diffusion of stable isotopes in polar firn and ice: the isotope effect in firn diffusion. In Hondoh T. ed. Physics of ice core records. Hokkaido University Press, Sapporo

Kinnard C, Zdanowicz CM, Fisher DA and Wake CP (2006) Calibration of an ice-core glaciochemical (sea-salt) record with sea-ice variability in the Canadian Arctic. Ann. Glaciol., 44, 383-390 (doi: 10.3189/172756406781811349)

Kinnard C, Zdanowicz CM, Fisher DA, Isaksson E, de Vernal A and Thompson LG (2011) Reconstructed changes in Arctic sea ice over the past 1,450 years. Nature, 479(7374), 509 (doi: 10.1038/nature10581)

Koffman BG, Handley M, Osterberg E, Wells ML and Kreutz K (2014) Dependence of ice-core relative trace-element concentration on acidification. J. Glaciol., 60(219), 103-112 (doi: 10.3189/2014JoG13J137)

Legrand M (1997) Ice-core records of atmospheric sulphur. Phil. Trans. R. Soc. London, Ser. B, 352(1350), 241-250 (doi: 10.1098/rstb.1997.0019)

Legrand M and 6 others (1997) Sulfur-containing species (methanesulfonate and $\mathrm{SO}_{4}$ ) over the last climatic cycle in the Greenland Ice Core Project (central Greenland) ice core. J. Geophys. Res., 102(C12), 26 663-26679 (doi: 10.1029/97jc01436)

Levine J, Yang X, Jones A and Wolff E (2014) Sea salt as an ice core proxy for past sea ice extent: a process-based model study. J. Geophys. Res., 119, 5737-5756 (doi: 10.1002/ 2013JD020925)

Levy LB, Kelly MA, Howley JA and Virginia RA (2012) Age of the Orkendalen moraines, Kangerlussuaq, Greenland: constraints on the extent of the southwestern margin of the Greenland Ice Sheet during the Holocene. Quat. Sci. Rev., 52, 1-5 (doi: 10.1016/j.quascirev.2012.07.021)
Masson-Delmotte $V$ and 9 others (2005) Rapid climate variability during warm and cold periods in polar regions and Europe. C. $R$. Geosci., 337(10-11), 935-946 (doi: 10.1016/j.crte.2005.04.001)

Mayewski PA and 6 others (1997) Major features and forcing of high-latitude northern hemisphere atmospheric circulation using a 110,000-year-long glaciochemical series. J. Geophys. Res., 102(C12), 26 345-26366 (doi: 10.1029/96jc03365)

Mei ZP and 6 others (2003) Phytoplankton production in the North Water Polynya: size-fractions and carbon fluxes, April to July 1998. Mar. Ecol. Progr. Ser., 256, 13-27 (doi: 10.3354/ meps256013)

Melling H, Gratton Y and Ingram G (2001) Ocean circulation within the North Water Polynya of Baffin Bay. Atmos.-Ocean, 39(3), 301-325 (doi: 10.1080/07055900.2001.9649683)

Merlivat $L$ and Jouzel J (1979) Global climatic interpretation of the deuterium-oxygen-18 relationship for precipitation J. Geophys. Res., 84(NC8), 5029-5033 (doi: 10.1029/JC084iC08p05029)

Mernild SH, Hanna E, Yde JC, Cappelen J and Malmros JK (2014) Coastal Greenland air temperature extremes and trends 1890-2010: annual and monthly analysis. Int. J. Climate, 34(5), 1472-1487 (doi: 10.1002/joc.3777)

Meyerson EA, Mayewski PA, Kreutz KJ, Meeker LD, Whitlow SI and Twickler MS (2002) The polar expression of ENSO and sea-ice variability as recorded in a South Pole ice core. Ann. Glaciol., 35, 430-436 (doi: 10.3189/172756402781817149)

Mulvaney R, Pasteur E, Peel D, Saltzman E and Whung PY (1992) The ratio of MSA to non-sea-salt sulfate in Antarctic Peninsula ice cores. Tellus, 44(4), 295-303 (doi: 10.1034/j.16000889.1992.t012-00007)

Osterberg EC, Handley MJ, Sneed SB, Mayewski PA and Kreutz KJ (2006) Continuous ice core melter system with discrete sampling for major ion, trace element, and stable isotope analyses. Environ. Sci. Tech., 40(10), 3355-3361 (doi: 10.1021/ es052536w)

Osterberg EC and 6 others (2014) Mount Logan ice core record of tropical and solar influences on Aleutian Low variability: 5001998 A.D. J. Geophys. Res., 119, 11 189-11 204 (doi: 10.1002/ 2014JD021847)

Perovich DK and Richter-Menge JA (2009) Loss of sea ice in the Arctic. Annu. Rev. Mar. Sci., 1, 417-441 (doi: 10.1146/annurev. marine.010908.163805)

Perrette M, Yool A, Quartly GD and Popova EE (2011) Nearubiquity of ice-edge blooms in the Arctic. Biogeosci., 8(2), 515-524 (doi: 10.5194/bg-8-515-2011)

Petit JR, White JWC, Young NW, Jouzel J and Korotkevich YS (1991) Deuterium excess in recent Antarctic snow. J. Geophys. Res., 96(D3), 5113-5122 (doi: 10.1029/90jd02232)

Polashenski C and 7 others (2014) Observations of pronounced Greenland ice sheet firn warming and implications for runoff production. Geophys. Res. Lett., 41(12), 4238-4246 (doi: 10.1002/2014gl059806)

Rankin AM, Wolff EW and Martin S (2002) Frost flowers: implications for tropospheric chemistry and ice core interpretation. J. Geophys. Res., 107(D23), AAC4-1-AAC4-12 (doi: 10.1029/2002jd002492)

Rayner NA and 7 others (2003) Global analyses of sea surface temperature, sea ice, and night marine air temperature since the late nineteenth century. J. Geophys. Res., 108(D14) (doi: 10.1029/2002jd002670)

Rhodes RH, Bertler NAN, Baker JA, Sneed SB, Oerter H and Arrigo KR (2009) Sea ice variability and primary productivity in the Ross Sea, Antarctica, from methylsulphonate snow record. Geophys. Res. Lett., 36 (doi: 10.1029/2009gl037311)

Rhodes RH and 6 others (2012) Little Ice Age climate and oceanic conditions of the Ross Sea, Antarctica from a coastal ice core record. Climate Past, 8(4), 1223-1238 (doi: 10.5194/cp-8-12232012)

Sasgen I and 8 others (2012) Timing and origin of recent regional ice-mass loss in Greenland. Earth Planet. Sci. Lett., 333, 293-303 (doi: 10.1016/j.epsl.2012.03.033) 
Schlesinger ME and Ramankutty N (1994) An oscillation in the global climate system of period 65-70 years. Nature, 367(6465), 723-726 (doi: 10.1038/367723a0)

Serreze MC, Barrett AP, Slater AG, Steele M, Zhang J and Trenberth KE (2007) The large-scale energy budget of the Arctic. J. Geophys. Res., 112(D11) (doi: 10.1029/2006jd008230)

Sharma $S$ and 13 others (2012) Influence of transport and ocean ice extent on biogenic aerosol sulfur in the Arctic atmosphere. J. Geophys. Res., 117 (doi: 10.1029/2011jd017074)

Shepherd A and 46 others (2012) A reconciled estimate of ice-sheet mass balance. Science, 338(6111), 1183-1189 (doi: 10.1126/ science.1228102)

Sinclair KE, Bertler NAN, Bowen MM and Arrigo KR (2014) Twentieth century sea-ice trends in the Ross Sea from a highresolution, coastal ice-core record. Geophys. Res. Lett., 41(10), 3510-3516 (doi: 10.1002/2014gl059821)

Sneed SB, Mayewski PA and Dixon DA (2011) An emerging technique: multi-ice-core multi-parameter correlations with Antarctic sea-ice extent. Ann. Glaciol., 52(57), 347-354 (doi: 10.3189/172756411795931822)

Steffen K and Box JE (2001) Surface climatology of the Greenland ice sheet: Greenland Climate Network 1995-1999. J. Geophys. Res., 106(D24), $33951-33964$ (doi: 10.1029/ 2001JD900161)

Stirling I (1997) The importance of polynyas, ice edges, and leads to marine mammals and birds. J. Mar. Syst., 10(1-4), 9-21 (10.1016/s0924-7963(96)00054-1)

Vidussi F and 7 others (2004) Spatial and temporal variability of the phytoplankton community structure in the North Water
Polynya, investigated using pigment biomarkers. Can. J. Fish. Aquat. Sci., 61(11), 2038-2052 (doi: 10.1139/fo4-152)

Vimeux F, Masson V, Jouzel J, Stievenard M and Petit JR (1999) Glacial-interglacial changes in ocean surface conditions in the southern hemisphere. Nature, 398(6726), 410-413 (doi: 10.1038/18860)

Vinther BM and 13 others (2009) Holocene thinning of the Greenland ice sheet. Nature, 461(7262), 385-388 (doi: 10.1038/nature08355)

Welch KA, Mayewski PA and Whitlow SI (1993) Methanesulfonic acid in coastal Antarctic snow related to sea-ice extent. Geophys. Res. Lett., 20(6), 443-446

Whung PY, Saltzman ES, Spencer MJ, Mayewski PA and Gundestrup N (1994) 200-year record of biogenic sulfur in a South Greenland ice core (20D). J. Geophys. Res., 99(D1), 1147-1156 (doi: 10.1029/93jd02732)

Wolff EW, Rankin AM and Rothlisberger R (2003) An ice core indicator of Antarctic sea ice production? Geophys. Res. Lett., 30(22) (doi: 10.1029/2003gl018454)

Wong GJ, Osterberg EC, Hawley RL, Courville ZR, Ferris D and Howley JA (2015) Coast-to-interior gradient in recent northwest Greenland precipitation trends (1952-2012). Environ. Res. Lett.

Yang X, Pyle J and Cox R (2008) Sea salt aerosol production and bromine release: role of snow on sea ice. Geophys. Res. Lett., 35, L16815

Yoshimori M and Abe-Ouchi A (2012) Sources of spread in multimodel projections of the Greenland Ice Sheet surface mass balance. J. Climate, 25(4), 1157-1175 (doi: 10.1175/ 2011jcli4011.1)

MS received 2 April 2015 and accepted in revised form 28 September 2015 